\title{
Al(III) speciation distribution and transformation in high concentration PACl solutions
}

\author{
HUANG Li', TANG Hong-xiao', WANG Dong-sheng ${ }^{1, *}$, WANG Shui-feng ${ }^{2}$, DENG Zai-jun ${ }^{2}$ \\ (1. State Key Lab of Environmental Aqueous Chemistry, Research Center for Eco-Environmental Sciences, Chinese Academy of Sciences, Beijing \\ 100085, China. E-mail: wgds (a)rcees.ac.cn; 2. Analytical and Testing Center, Beijing Normal University, Beijing 100875, China)
}

\begin{abstract}
Effects of $\mathrm{Al}(\mathrm{III})$ concentration and $\mathrm{pH}$ on the speciation of $\mathrm{Al}(\mathrm{III})$ in polyaluminum chloride (PACl) solutions especially on the $\mathrm{Al}_{13}$ fraction were investigated. A series of $\mathrm{PACl}$ samples were prepared over the range of $\mathrm{Al}(\mathrm{III})$ concentration from 0.01 to 2.0 $\mathrm{mol} / \mathrm{L}$ with the $B\left(\mathrm{OH} / \mathrm{Al}\right.$ ratio) valuc from 1.0 to 2.5 by forced hydrolysis of $\mathrm{AlCl}_{3}$. The samples were characterized by ferron assay, $\mathrm{pH}$ and ${ }^{27} \mathrm{Al}$ NMR. It was shown that the $\mathrm{Al}(\mathrm{III})$ concentration had a dramatic effect on the hydrolysis processes and the species distribution of $\mathrm{PACl}$ was in relate to the decrease of $\mathrm{pH}$. The fraction of $\mathrm{Al}$ species, $\mathrm{Al}_{\mathrm{b}}$ (or $\mathrm{Al}_{13}$ ) decreased and $\mathrm{Al}_{\mathrm{c}}$ increased with increase of total $\mathrm{Al}(\mathrm{III})$ concentration. Under the condition of $\mathrm{Al}(\mathrm{III}) 2.0 \mathrm{~mol} / \mathrm{L}, B=2.5$, the $\mathrm{pH}$ value was 2.73 and no $\mathrm{Al}_{13}$ could be detected. During diluting and aging, the species distribution evolved. The $\mathrm{Al}_{13}$ could then be detected again and the amounts increased with time. If the diluted samples were concentrated by freeze dry at $-35^{\circ} \mathrm{C}$ or heating at $80^{\circ} \mathrm{C}$, the pH value and $\mathrm{Al}_{13}$ content would decrease with the increased concentration. It demonstrated that the key factor for formation of $\mathrm{Al}_{13}$ in concentrated $\mathrm{PACl}$ was $\mathrm{pH}$ value.
\end{abstract}

Keywords: $\mathrm{PACl} ; \mathrm{Al}_{13} ; B$ value; $\mathrm{pH}$; speciation

\section{Introduction}

Since water pollution has become a worldwide problem, many countries suffered from lack of quantity of source water to high quality and safe water or both. Increased attention has been paid to the purification of water in recent years. The effective coagulants must play a more important role in water and wastewater treatment. The inorganic polymer flocculant (IPF) of polyaluminum chloride (PACl) gained broadest use in the world because of its high efficiency and low toxicity compared with the organic reagents (Stumm and Morgan, 1962; Tang, 1998; Parthasarathy and Buffle, 1985; Wang and Tang, 2001; Wang el al., 2002). Researches concerning $\mathrm{PACl}$ started to be an active topic in the field of environmental science and technology.

The hydrolysis reaction of aqueous $\mathrm{Al}(\mathrm{III})$ has been the subject of innumerable investigations over the passed century. Especially in recent 30 years, the great progress in characterizing the species of $\mathrm{PACl}$ and their transformation has been achieved due to the application of the advanced methods of timedcomplexation absorption and ${ }^{27} \mathrm{Al}$ NMR spectroscopy. It is accepted prevalently that the Al(III) ions in partially neutralized solution exhibit strong hydrolysis reactions and various polynuclear or polymer species in metastable state can be formed (Tang, 1998; Wang and Tang, 2001; Wang et al., 2002; Bersillon et al., 1980; Parker and Bertsch, 1992; Hsu, 1988; Akitt and Alan, 1981; Bottero et al., 1987, 1988; Brosset, 1952; Rowsell and Nazar, 2000; Allouche et al, 2000; Kloprogge et al., 1993). The ferron assay can divide the $\mathrm{Al}(\mathrm{III})$ species into $\mathrm{Al}_{a}, \mathrm{Al}_{b}$ and $\mathrm{Al}_{c}$ categories. The ${ }^{27} \mathrm{Al}$ NMR spectroscopy can identify the monomer, oligomer and tridecamer $\left(\mathrm{Al}_{13}\right)$ species in special. The species distribution of $\mathrm{PACl}$ depends on the preparing conditions, such as $\mathrm{OH} / \mathrm{Al}$ molar ratio $(B)$, total concentration of $\mathrm{Al}$, rate of base addition, and temperature and so on.

It was gradually recognized that $\mathrm{Al}_{13}$ is the most effective species for charge neutralization and particle bridging actions in coagulation and flocculation processes (Bottero, 1988; Tang, 1998; Xu et al., 2003; Wang et al., 2004; Tang and Luan, 1996). However, $\mathrm{Al}_{13}$ is only one kind of the complicated hydrolyzed $\mathrm{Al}$ (III) species, which coexists with other species in $\mathrm{PACl}$ and its content depends greatly on the preparation conditions. For the $\mathrm{PACl}$ prepared in laboratory with concentration less than $0.5 \mathrm{~mol} / \mathrm{L} \mathrm{Al}$ (III), the content of $\mathrm{Al}_{13}$ can usually reach $70 \%$ more. But $\mathrm{Al}_{\mathrm{b}}$ content can be less than $30 \%$ in current industrial liquid $\mathrm{PACl}$ products at concentration above $2 \mathrm{~mol} / \mathrm{L}$ Al(III) (Xu et al., 2003; Wang et al., 2004; Tang and Luan, 1996). Therefore, how to produce PACl with high $\mathrm{Al}_{13}$ content becomes an important target of PACl production and polymeric solution chemistry of $\mathrm{Al}(\mathrm{III})$ as well. However, most of the previous studies focused on the solutions of low concentration of $10^{-4}-10^{-1} \mathrm{~mol} / \mathrm{L}$ and few concerned with the high concentration about $1-2 \mathrm{~mol} / \mathrm{L}$. It is necessary to further investigate the cause of very low $\mathrm{Al}_{13}$ or $\mathrm{Al}_{b}$ content in high Al(III) concentration PACl.

This investigation was focused on the series speciation characterization in concentrated and diluted $\mathrm{Al}(\mathrm{III})$ solutions by using ferron assay and ${ }^{27} \mathrm{Al} \mathrm{NMR}$ 
spectroscopy. It was aimed to enhance our understanding of the characteristics of $\mathrm{PACl}$ with high concentration and the mechanism of decrease of $\mathrm{Al}_{13}$ content.

\section{Material and methods}

\subsection{Preparation of PACI}

All PACl samples were prepared in a $500-\mathrm{ml}$ double-walled, heat-resistant glass vessel. The solution in the reactor was maintained at $80^{\circ} \mathrm{C}$ by circulating water from a thermostatically controlled water bath. $2.0 \mathrm{~mol} / \mathrm{L} \mathrm{Al}$ stock solution was prepared by dissolving $\mathrm{AlCl}_{3} \cdot 6 \mathrm{H}_{2} \mathrm{O}$ in deionized water. The amount of deionized water and $\mathrm{Na}_{2} \mathrm{CO}_{3}$ added were determined according to the final $\mathrm{Al}$ (III) concentration and $B$ value desired. $\mathrm{Na}_{2} \mathrm{CO}_{3}$ was added into the $\mathrm{AlCl}_{3}$ solution with a certain slow rate. The species distribution of $\mathrm{PACl}$ was characterized by ferron assay and ${ }^{27} \mathrm{Al}$ NMR spectroscopy. The total $\mathrm{Al}(\mathrm{III})\left(\mathrm{Al}_{\mathrm{T}}\right)$ concentration was measured by ICP.

\subsection{Dilution of high concentration PACl}

In this investigation, the $2.0 \mathrm{~mol} / \mathrm{L} \mathrm{PACls}$ at $B$ value of $1.5,2.0,2.5$ prepared by the above-mentioned method were diluted with deionized water to the final concentration of $1.0,0.5,0.2,0.1$ and $0.05 \mathrm{~mol} / \mathrm{L}$ at $25^{\circ} \mathrm{C}$, respectively. The species distribution of diluted $\mathrm{PACl}$ was characterized by ferron assay and ${ }^{27} \mathrm{Al} \mathrm{NMR}$ spectroscopy as well. The transformation of species of $\mathrm{PACl}$ in one month of aging at $25^{\circ} \mathrm{C}$ after dilution has also been studied.

\subsection{Reconcentrating of $\mathrm{PACl}$}

The reconcentrating of $\mathrm{PACl}$ was carried out in two ways of vacuum freeze-dry or heating dry. The samples were prepared by diluting $2.0 \mathrm{~mol} / \mathrm{L} \mathrm{PACl}(B$ $=2.5$ ) to $0.1 \mathrm{~mol} / \mathrm{L}$ and then concentrated reverse in vacuum desiccators at $-35^{\circ} \mathrm{C}$ or in water bath at $80^{\circ} \mathrm{C}$. The final Al concentrations were approached to 0.5 , 1.0 and $2.0 \mathrm{~mol} / \mathrm{L}$ respectively. The concentrated $\mathrm{PACl}$ samples were characterized by ferron assay, $\mathrm{pH}$ and ${ }^{27} \mathrm{Al}$ NMR spectroscopy.

\subsection{Ferron assay}

Based on the kinetic difference of the reactions between the Al species and ferron reagent (8-hydroxy-7-iodoquinoline-5-sulfonic acid), the $\mathrm{Al}$ species can be divided into $\mathrm{Al}_{\mathrm{a}}, \mathrm{Al}_{\mathrm{b}}$ and $\mathrm{Al}_{\mathrm{c}}$ categories, respectively (Wang et al., 2002). The timed absorbance measurements were carried out on UV-Vis 800 Spectrometer at $366 \mathrm{~nm}$ and the readings were picked at $1 \mathrm{~min}$ and $120 \mathrm{~min}$ after mixing the sample with ferron reagent. It was operationally divided that the 1 min absorbance as $\mathrm{Al}_{\mathrm{a}}$, and 1 min to $2 \mathrm{~h}$ as $\mathrm{Al}_{\mathrm{b}}$, then the concentration of $\mathrm{Al}_{\mathrm{c}}$ was obtained from the remainder of $\mathrm{Al}_{T}$.

\section{$1.5{ }^{27} \mathrm{Al}$ NMR spectroscopy analyses}

The measurements were carricd out on a Bruker Advance 500 NMR spectrometer at $52.14 \mathrm{MHz}$ and the methods was addressed in details elsewhere ( $\mathrm{Xu}$ et al., 2003). The other spectral parameters were: temperature $293 \mathrm{~K}$, number of scan 128 , pulse width $14.0 \mu \mathrm{s}$. The $0.05 \mathrm{~mol} / \mathrm{L} \mathrm{NaAlO}_{2}$ solution diluted with $\mathrm{D}_{2} \mathrm{O}$ was used as reference with respect to the chemical shift $(\delta)$ for all solutions, which causes the resonance peak at chemical shift $\delta=80$ in spectrum. The concentration of $\mathrm{Al}_{13}$ was calculated by the integral of resonance peak at about $62.5(\delta)$ multiply 13. The concentrations of $\mathrm{Al}$-monomer and Al-oligomer were taken from the integral intensities of corresponding resonance peaks at about 0 and $4(\delta)$. The undetectable $\mathrm{Al}$ was obtained from the remainder of the $\mathrm{Al}_{\mathrm{T}}$.

\subsection{General methods}

The measurement of $\mathrm{pH}$ value was carried out on Orion pH meter (Model 828) with glass-electrode system. The measurement of $\mathrm{Al}_{\mathrm{T}}$ was carried out on YJ ULTIMA ICP-AES. Deionized water prepared by RO processing free from trace organic compounds. All the chemicals used in this study were of analytical grade unless otherwise pointed out.

\section{Results and discussion}

\subsection{Speciation characterization in PACl of high concentration}

The distribution of $\mathrm{Al}$ species of various $\mathrm{PACl}$ samples characterized by ferron assay is summarized in Table 1. All the samples were prepared as described in Section 1 over the range of concentration from 0.01

\begin{tabular}{|c|c|c|c|c|c|c|}
\hline No. & Value $B$ & $\mathrm{Al}_{\mathrm{I}}, \mathrm{mol} / \mathrm{L}$ & $A l_{a}, \%$ & $A]_{b} \%$ & $\mathrm{Al}_{\mathrm{c}}, \%$ & $\mathrm{pH}$ \\
\hline 1 & 1.5 & 0.01 & 39.5 & 52.8 & 7.7 & 3.98 \\
\hline 2 & 2.0 & 0.01 & 26.5 & 71.3 & 2.2 & 4.27 \\
\hline 3 & 2.5 & 0.01 & 5.4 & 81.9 & 5.0 & 5.44 \\
\hline 4 & 1.0 & 0.1 & 59.4 & 35.1 & 2.9 & 3.46 \\
\hline 5 & 1.5 & 0.1 & 44.4 & 52.1 & 3.5 & 3.60 \\
\hline 6 & 2.0 & 0.1 & 25.3 & 72.6 & 2.1 & 3.78 \\
\hline 7 & 2.5 & 0.1 & 4.5 & 73.6 & 21.9 & 5.32 \\
\hline 8 & 0 & 0.5 & 100 & 0 & 0 & 2.71 \\
\hline 9 & 1.0 & 0.5 & 66.7 & 29.3 & 4.0 & 3.40 \\
\hline 10 & 1.5 & 0.5 & 45.7 & 38.1 & 16.2 & 3.44 \\
\hline 11 & 2.0 & 0.5 & 30.2 & 50.1 & 19.7 & 3.51 \\
\hline 12 & 2.2 & 0.5 & 20.2 & 54.7 & 20.1 & 3.59 \\
\hline 13 & 2.4 & 0.5 & 13.1 & 59.7 & 27.2 & 3.75 \\
\hline 14 & 2.5 & 0.5 & 6.8 & 63.2 & 30.0 & 4.19 \\
\hline 15 & 2.5 & 1.1 & 4.7 & 19.7 & 75.6 & 3.44 \\
\hline 16 & 2.5 & 1.8 & 4.2 & 10.0 & 85.8 & 3.12 \\
\hline 17 & 0 & 2.0 & 100 & 0 & 0 & 0.63 \\
\hline 18 & 1.0 & 2.0 & 75.5 & 18.3 & 6.2 & $-*$ \\
\hline 19 & 1.5 & 2.0 & 56.1 & 13.4 & 30.5 & 2.18 \\
\hline 20 & 2.0 & 2.0 & 32.9 & 8.8 & 58.3 & 2.39 \\
\hline 21 & 2.3 & 2.0 & 11.5 & 7.5 & 81.0 & 2.42 \\
\hline 22 & 2.5 & 2.0 & 6.9 & 8.0 & 85.1 & 2.73 \\
\hline
\end{tabular}


to $2.0 \mathrm{~mol} / \mathrm{L}$. The $\mathrm{pH}$ of samples is also listed. The distribution of $\mathrm{Al}$ species is plotted vs. $\mathrm{Al}$ (III) concentration and $B$ values respectively (Fig. 1). From Fig.1, it can be recognized that the $\mathrm{Al}_{\mathrm{b}}$ fraction decreases and the $\mathrm{Al}_{\mathrm{c}}$ fraction increases sharply with the increasing of Al (III) concentration especially from $0.5 \mathrm{~mol} / \mathrm{L}$ while the $\mathrm{Al}_{\mathrm{a}}$ fraction increases moderately at the same
$B$ value. For the high concentration $\mathrm{PACl}$ at $2.0 \mathrm{~mol} / \mathrm{L}$ Al (III), the $\mathrm{Al}_{\mathrm{a}}$ fraction begins to decrease rapidly while the $\mathrm{Al}_{\mathrm{c}}$ fraction increases rapidly with increase of $B$ value. The $\mathrm{Al}_{\mathrm{c}}$ becomes the predominant species over $B=2.0$. It shows that the $A l_{b}$ fraction is very limited in high concentration of Al.

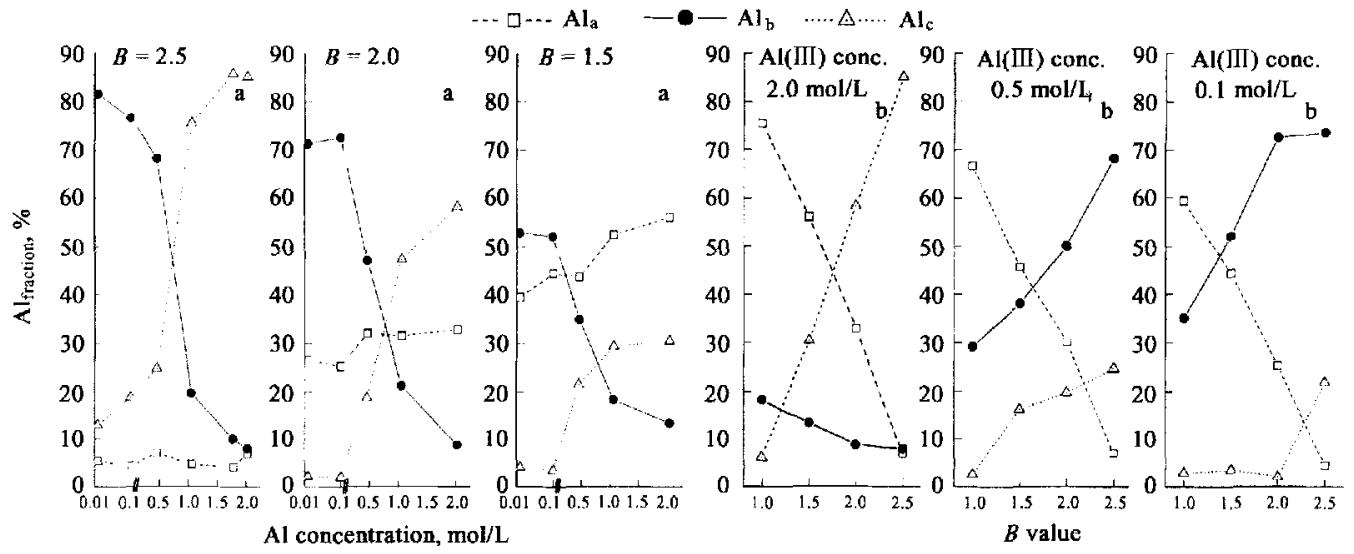

Fig.l Species distribution of PACl characterized by ferron assay a. various concentration of $\mathrm{Al}(\mathrm{III})$; $\mathrm{b}$. various $B$ value

The fractions of $\mathrm{Al}_{13}, \mathrm{Al}$-monomer and $\mathrm{Al}$ oligomer of samples by ${ }^{27} \mathrm{Al}$ NMR spectrum are calculated from the integral intensities of corres- ponding resonance peaks and summarize in Table 2 . The $\mathrm{Al}_{\mathrm{T}}$ and undetectable $\mathrm{Al}$ fraction are listed as well.

Table 2 Speciation characterization of PACl by ${ }^{n} \mathrm{Al}$ NMR spectra

\begin{tabular}{|c|c|c|c|c|c|c|c|c|c|}
\hline \multirow{2}{*}{$\begin{array}{c}\text { Al(III) } \\
\text { conc., } \mathrm{mol} / \mathrm{L}\end{array}$} & \multirow{2}{*}{$B$ value } & \multicolumn{4}{|c|}{ Intensity } & \multicolumn{4}{|c|}{ Fraction, $\%$} \\
\hline & & $\delta=0$ & $\delta=4$ & $\delta=10$ & $\delta=63$ & $A 1_{1 \mathrm{~mm} \times}$ & $\mathrm{Al}_{\mathrm{b}}$ & $\mathrm{Al}_{13}$ & $A I_{\text {IIn }}$ \\
\hline 0.1 & 1.0 & 4.19 & 0.05 & - & 0.2 & 44.0 & 2.1 & 20.2 & 33.7 \\
\hline 0.1 & 1.5 & 3.52 & - & - & 0.41 & 36.9 & - & 49.3 & 13.8 \\
\hline 0.1 & 2.0 & 1.48 & - & - & 0.51 & 15.2 & - & 63.1 & 21.7 \\
\hline 0.1 & 2.5 & - & - & - & 0.34 & - & - & 39.6 & 60.4 \\
\hline 0.5 & 2.0 & 8.56 & 0.75 & - & 1.03 & 17.2 & 1.7 & 29.6 & 51.5 \\
\hline 0.5 & 2.2 & 4.26 & 0.20 & - & 1.50 & 8.7 & 0.6 & 41.6 & 49.1 \\
\hline 0.5 & 2.4 & 1.74 & - & - & 1.92 & 3.7 & - & 52.6 & 43.7 \\
\hline 0.5 & 2.5 & 0.45 & - & - & 2.08 & 1.2 & - & 56.7 & 42.1 \\
\hline 2.0 & 1.5 & 45.83 & 4.61 & - & - & 22.8 & 2.3 & - & 74.9 \\
\hline 2.0 & 2.0 & 23.22 & 1.65 & - & - & 11.6 & 0.9 & - & 87.5 \\
\hline 2.0 & 2.5 & 4.34 & - & - & - & 2.2 & - & - & 97.8 \\
\hline
\end{tabular}

Notes: $\mathrm{Al}_{\mathrm{nm} \text { m. }}$ Al-monomer; $\mathrm{Al}_{1,}$ Al-oligomer; $\delta$. chemical shift

Fig. 2 shows the ${ }^{27} \mathrm{Al}$ NMR spectra of $0.5 \mathrm{~mol} / \mathrm{L}$ $\mathrm{PACl}$ over the range of $B$ from 2.0 to 2.5 and 2.0 $\mathrm{mol} / \mathrm{L} \mathrm{PACl}$ over the range of $B$ from 1.5 to 2.5 respectively. Comparison of Fig.2b with Fig.2a, it can be recognized that no $\mathrm{Al}_{13}$ can be detected in $\mathrm{PACl}$ at $2.0 \mathrm{~mol} / \mathrm{L} \mathrm{Al}$ (III) concentration. The concentration of monomer and oligomer decreases with the increase of $B$ value, which is similar to the situation in $\mathrm{PACl}$ at $0.5 \mathrm{~mol} / \mathrm{L} \mathrm{Al}$ (III) concentration. However, the concentration of undetectable species is increasing rapidly with the increasing of $B$ value (Table 2).

Fig. 3 shows the effect of aging on the species of $\mathrm{PACl}$ in high concentration. The ${ }^{27} \mathrm{Al}$ NMR spectrum of $\mathrm{PACl}(2.0 \mathrm{~mol} / \mathrm{L}, B=2.5)$ fresh prepared presents only the signal of monomer while aged 2 months the $\mathrm{PACl}(2.0 \mathrm{~mol} / \mathrm{L}, B=2.5)$ presents a middle intensity and broad peak at chemical shift about $\delta=10$ nearby the signal of monomer. With the signal appearing at $\delta$ $=10$, the peak of monomer decreases. It is believed that the resonance peak at chemical shift about $10(\delta)$ 

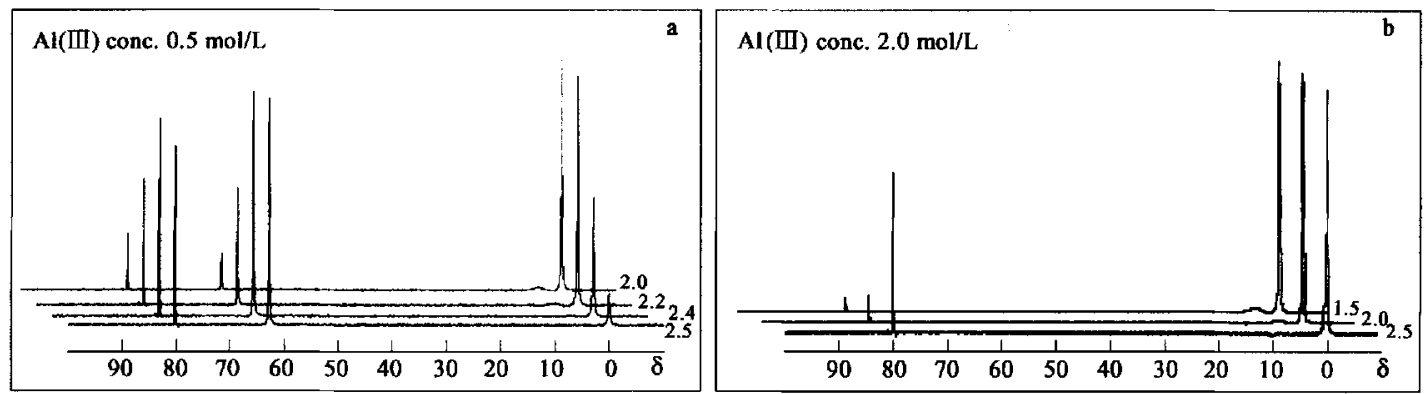

Fig. $2{ }^{27} \mathrm{Al}$ NMR spectra of $\mathrm{PACl}$ prepared by adding $\mathrm{Na}_{2} \mathrm{CO}_{3}$ solution to $\mathrm{AlCl}_{3}$ stock solution at $80^{\circ} \mathrm{C}$

a. $\mathrm{Al}(\mathrm{III})$ conc. $0.5 \mathrm{~mol} / \mathrm{L}$, from far to near represent, $B=2.0,2.2,2.4,2.5$ respectively; b. Al(III) conc. $2.0 \mathrm{~mol} / \mathrm{L}$, from far to near represent $B$ $=1.5,2.0,2.5$ respectively

is caused by octahedral $\mathrm{Al}(\mathrm{III})$ connected with tetrahedral Al(III) (Akitt, 1989). It indicates that the tetrahedral Al(III) may exist with asymmetric structure in fresh prepared $\mathrm{PACl}$ and it connects with octahedral Al(III) during aging. However, the structure of this species has not been identified yet. It seems different from $\mathrm{Al}_{30}$, the species reported by Allouche et al. (2000).

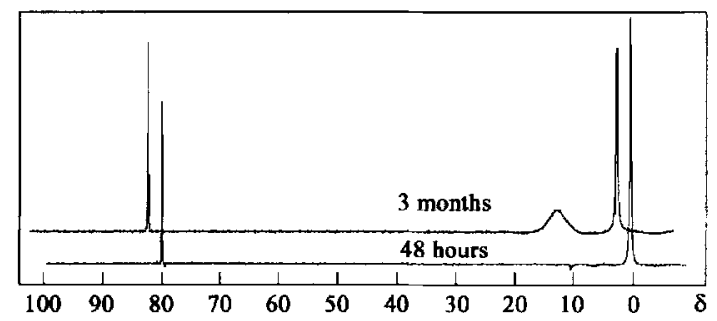

Fig. $3{ }^{27} \mathrm{Al}$ NMR spectra of $2.0 \mathrm{~mol} / \mathrm{L} \mathrm{PACl}$ prepared by adding $\mathrm{Na}_{2} \mathrm{CO}_{3}$ into $\mathrm{AlCl}_{3}$ solution at $80^{\circ} \mathrm{C}$ with $B$ value of 2.5 by aging

Upon comparison of the results obtained by ferron assay and ${ }^{27} \mathrm{Al}$ NMR spectroscopy methods, it indicates that the increasing of $\mathrm{Al}_{\mathrm{T}}$ concentration favors the formation of larger polymer species beyond $\mathrm{Al}_{13}$. The $\mathrm{Al}_{13}$ fraction decreases sharply with the increasing of total $\mathrm{Al}(\mathrm{III})$ concentration. The influence of total concentration on oligomer is not significant. The amount of monomer increases a little with the increasing of total $\mathrm{Al}(\mathrm{III})$ concentration. It indicates the decrease of $\mathrm{Al}_{13}$ with the yield of undetectable species in ${ }^{27} \mathrm{Al}$ NMR analysis or $\mathrm{Al}_{\mathrm{c}}$ fraction in ferron assay is not a simple aggregation of $\mathrm{Al}_{13}$. It is difficulty for $\mathrm{Al}$ (III) to form $\mathrm{Al}_{13}$ at high $\mathrm{Al}(\mathrm{III})$ concentration.

2.2 Effect of concentration on the formation and transformation of $\mathbf{A l}_{13}$ or $\mathbf{A l}_{\mathbf{b}}$ species

Fig.4 shows the species evolution in $\mathrm{PACl}$ solutions that were diluted from $2.0 \mathrm{~mol} / \mathrm{L}$ to various concentrations and then aged at $25^{\circ} \mathrm{C}$. Figs. $4 \mathrm{a}, 4 \mathrm{~b}$ and $4 \mathrm{c}$ are the $\mathrm{PACl}$ solutions with the $B$ value of $2.5,2.0$ and 1.5 respectively. It seems that the transformation of species in high concentration of $\mathrm{PACl}$ takes place during dilution. The variation of diluted solution depends largely on the $B$ value of primary solutions. After dilution, the $A l_{h}$ fraction of all samples starts to increase. The increments become slowed down after several days in the solutions of $B=2.0$ (Fig. $4 \mathrm{~b}$ ) and $B$ $=1.5$ (Fig.4c) but continued to increase in the solutions of $B=2.5$ at lower concentration $\quad(<0.2$ $\mathrm{mol} / \mathrm{L}$ ) (Fig.4a).

For $\mathrm{Al}_{\mathrm{a}}$ species, the amount is decreasing with decreasing solution concentration. The variety is more obvious for $\mathrm{PACl}$ at lower $B$ value. Comparison of Fig. 4 with Fig. 1 shows a similar tendency of species distribution in the diluted solution and the $\mathrm{PACl}$ prepared in the same concentration.

For $\mathrm{Al}_{b}$ species, the fraction is increasing with decreasing solution concentration. The increment of $\mathrm{Al}_{\mathrm{b}}$ is larger at higher $B$ value. Although the $\mathrm{Al}_{\mathrm{b}}$ fraction formed during dilution is much less than prepared at the same concentration and $B$ value, it shows a similar tendency that the formation and stabilization of $\mathrm{Al}_{b}$ is unfavorable in high concentration. The $\mathrm{Al}_{\mathrm{b}}$ fraction is increasing with the increasing of $B$ value at last. It is needed to point out that the rate of $\mathrm{Al}_{\mathrm{b}}$ formation and the increment of $\mathrm{Al}_{b}$ during aging vary according to the different $B$ value. For diluted $\mathrm{PACl}$ at $B$ value of 1.5 or 2.0 , the increment of $\mathrm{Al}_{b}$ fraction is very rapidly during the first $3 \mathrm{~h}$ aging and then slows down. It almost reaches equilibrium until $1 \mathrm{~d}$ aging and this increment is very limited during the henceforth $29 \mathrm{~d}$ aging investigated. For diluted $\mathrm{PACl}$ at $B$ value of 2.5 , however, the $\mathrm{Al}_{\mathrm{b}}$ fraction is increasing continuously during one month aging. The higher $\mathrm{Al}_{\mathrm{a}}$ fraction is, the quicker $\mathrm{Al}_{b}$ forms. From Fig.4, it can also be observed that a large part of $\mathrm{Al}_{\mathrm{c}}$ species are colloidal $\mathrm{Al}(\mathrm{OH})_{3}$ which could not dissolve to form $\mathrm{Al}_{b}$ any more.

Fig. 5 shows the transformation of species after dilution and aging as identified by ${ }^{27} \mathrm{Al}$ NMR spectroscopy. It proves that $\mathrm{Al}_{13}$ has been formed during the dilution process. Upon comparison of Fig. 5 , it could be found that the formation rate of $\mathrm{Al}_{13}$ varied depending on the $B$ value. The signal of $\mathrm{Al}_{13}$ of $\mathrm{PACl}$ at $B$ value of 2.0 appears immediately after dilution. The concentration of $\mathrm{Al}_{13}$ is increasing obviously during the period of $150 \mathrm{~min}$ monitoring. The rate of $\mathrm{Al}_{13}$ formation of $\mathrm{PACl}$ at $B$ value of 2.5 , 


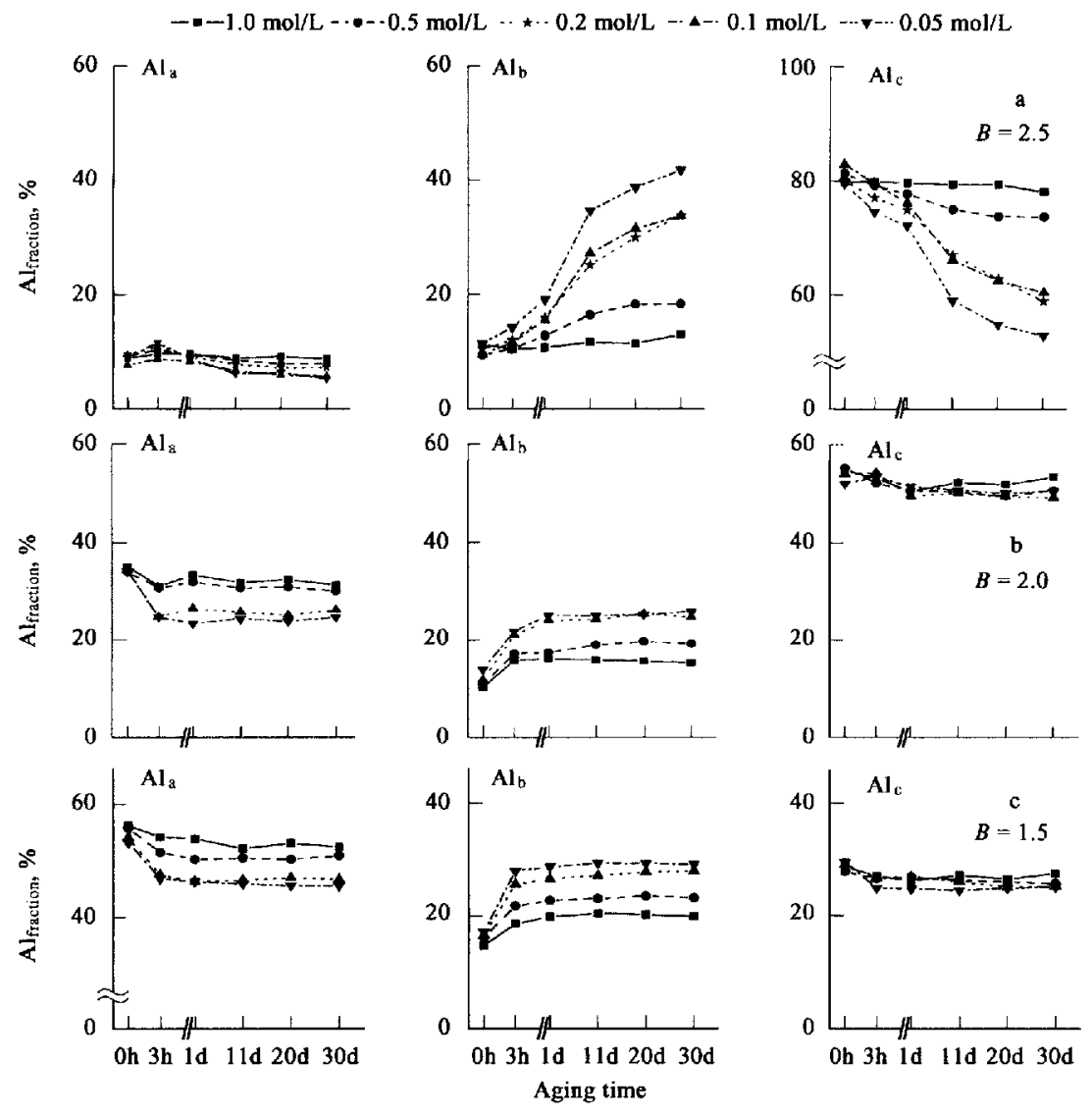

Fig.4 Speciation of $\mathrm{PACl}$ at various concentrations and the effect of aging time a. dilution with $B=2.5 ;$ b. dilution with $B=2.0 ; \mathrm{c}$. dilution with $B=1.5$

however, is much slower. A very weak signal of $\mathrm{Al}_{13}$ appears until 60 min aging. It seems that the $\mathrm{Al}_{13}$ fractions form via different ways. In the low $B$ value $\mathrm{PACl}$, the $\mathrm{pH}$ unequilibrium at interface arising from the addition of deionized water (weak base) during dilution causes the formation of $\mathrm{AlO}_{4}^{-}$because of the higher $\mathrm{Al}_{\mathrm{a}}$ content. Therefore the $\mathrm{Al}_{13}$ forms rapidly. In the high $B$ value $\mathrm{PACl}$, the disconnection of polymer takes place and the disconnection of polymer containing tetrahedral $\mathrm{Al}(\mathrm{III})$ can form $\mathrm{AlO}_{4}^{-}$that reacts with $\mathrm{Al}$-monomer or $\mathrm{Al}$-oligomer formed to form $\mathrm{Al}_{13}$. Since the dissolution of the polymer follows a slow kinetic and lasts a long period, the formation of $\mathrm{Al}_{13}$ increases gradually during aging. The results of ${ }^{27} \mathrm{Al}$ NMR spectra correspond well with ferron assay.

Fig.6 shows the ${ }^{27} \mathrm{Al}$ NMR spectra of the PACls concentrated by vacuum freeze dry and heating dry. The data of chemical shift and integral intensity of resonance and $\mathrm{pH}$ have been listed in Table 3 . It is easy to be recognized that the $\mathrm{Al}_{13}$ concentration is decreasing with the increasing of $\mathrm{Al}$ (III) concentration of $\mathrm{PACl}$ while the concentration of monomer is not increasing during concentrating. In addition, the species which causes chemical shift at about $10(\delta)$ is forming during concentration. This chemical shift moves to high field and its integral intensity increases

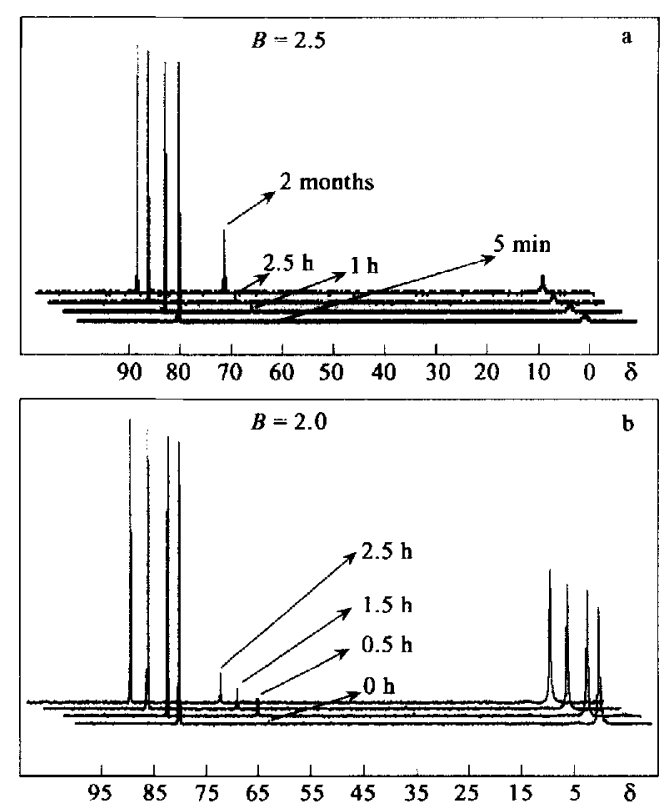

Fig.5 ${ }^{27} \mathrm{Al} \mathrm{NMR} \mathrm{spectra} \mathrm{of} \mathrm{PACl}$ diluted from 2.0 to $0.1 \mathrm{~mol} / \mathrm{L}$ a. dilution with $B=2.5$ aging $5 \mathrm{~min}, 1 \mathrm{~h}, 2.5 \mathrm{~h}, 2$ months from near to far respectively; b. dilution with $B-2.0$ aging $0 \mathrm{~min}, 30$ $\min , 1.5 \mathrm{~h}, 2.5 \mathrm{~h}$ from near to far respectively

with the increasing of concentration. The $\mathrm{Al}_{13}$ species has disappeared completely until the $\mathrm{PACl}$ has been 
Table 3 Characterization of concentrated PACl by ${ }^{27} \mathrm{AI}$ NMR spectroscopy

\begin{tabular}{cccccc}
\hline \multirow{2}{*}{$C_{\mathrm{N}}^{*}, \mathrm{~mol} / \mathrm{L}$} & $\mathrm{pH}$ & & \multicolumn{2}{c}{ Intensity } & \multirow{2}{*}{ Method of concentration } \\
\hline 1.0 & 3.56 & $\delta=63$ & $\delta=10$ & $\delta=0$ & Freeze dry at $-35^{\circ} \mathrm{C}$ \\
2.0 & 2.89 & 0.21 & 0.12 & 1.76 & Freeze dry at $-35^{\circ} \mathrm{C}$ \\
2.0 & 2.82 & - & 0.81 & 2.72 & Heating at $80^{\circ} \mathrm{C}$ \\
\hline
\end{tabular}

Notes: $\delta$. Chemical shift; * it was concentrated from $0.1 \mathrm{~mol} / \mathrm{L} \mathrm{PACl}$ at $\mathrm{pH} 4.44$

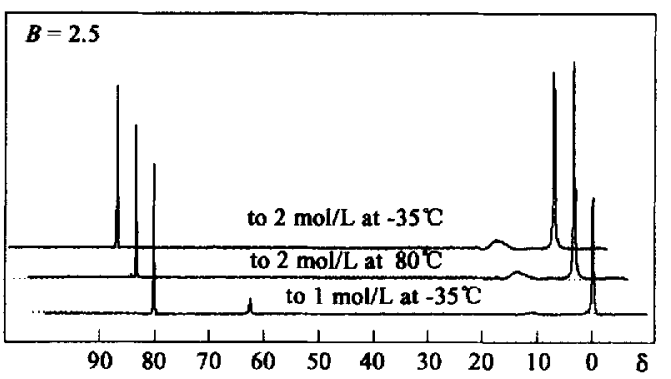

Fig. $6{ }^{27} \mathrm{Al}$ NMR spectra of the PACl $(B=2.5)$ (diluted from 2.0 $\mathrm{mol} / \mathrm{L}$ to $0.1 \mathrm{~mol} / \mathrm{L}$ and aged 2 months and then concentrated from $0.1 \mathrm{~mol} / \mathrm{L}$ to various concentrations under different conditions)

concentrated to $2.0 \mathrm{~mol} / \mathrm{L}$. Little difference can be found between the $\mathrm{PACl}$ concentrated by freeze dry at $-35^{\circ} \mathrm{C}$ and by heating at $80^{\circ} \mathrm{C}$. The temperature does not play a key role for the disappearance of $\mathrm{Al}_{13}$. It indicates that increasing concentration is unfavorable for the stabilization of $\mathrm{Al}_{13}$.

\subsection{Influence of $\mathrm{pH}$ on $\mathrm{Al}_{13}$}

The above results show that no $\mathrm{Al}_{13}$ exists in $\mathrm{PACl}$ with concentration exceeding $2.0 \mathrm{~mol} / \mathrm{L}$. Since $\mathrm{Al}_{13}$ is one of the products of partial hydrolyzed $\mathrm{Al}$ (III) solution, $\mathrm{pH}$ value will play important role in the formation and stabilization of $\mathrm{Al}_{13}$. Concentration is an indirect cause for the unfavorable formation and stabilization of $\mathrm{Al}_{13}$ in high concentration $\mathrm{PACl}$ solution. By referring Table 1, various Al(III) concentrations will result in the variety of $\mathrm{pH}$. Therefore, the variety of species distribution of $\mathrm{PACl}$ in various concentrations should be caused by the different $\mathrm{pH}$ values.

Fig.7 shows the relationship of $\mathrm{Al}_{13}$ of $\mathrm{PACl}$ in concentration of $0.01,0.1,0.5,2.0 \mathrm{~mol} / \mathrm{L}$ and $\mathrm{pH}$ value. The characteristics indicated that for $\mathrm{PACl}$ in $\mathrm{Al}(\mathrm{III})$ concentration of 0.01 and $0.1 \mathrm{~mol} / \mathrm{L}$, the $\mathrm{pH}$ over the $B$ range from 1.0 to 2.5 is from 3.52 and 3.78 to 5.32 and 5.44 respectively. The content of $\mathrm{Al}_{13}$ is increasing with the $\mathrm{pH}$ value first and then decreasing. The critical point is between 3.78 and 5.32. For $\mathrm{PACl}$ in $\mathrm{Al}(\mathrm{III})$ concentration of $0.5 \mathrm{~mol} / \mathrm{L}$, the $\mathrm{pH}$ over the $B$ range from 2.0 to 2.5 is from 3.51 to 4.19 . The content of $\mathrm{Al}_{13}$ is increasing with the $\mathrm{pH}$ value. For $\mathrm{PACl}$ in $\mathrm{Al}(\mathrm{III})$ concentration of $2.0 \mathrm{~mol} / \mathrm{L}$, the $\mathrm{pH}$ over the $B$ range from 1.5 to 2.5 is from 2.17 to 2.73 . However, no $\mathrm{Al}_{13}$ can be detected by ${ }^{27} \mathrm{Al}$ NMR spectroscopy. It indicates that $\mathrm{Al}_{13}$ forms under the condition of a certain range of $\mathrm{pH}$ values. The optimal range of $\mathrm{pH}$ values is about between 3.5 and 5 . Under the condition of $\mathrm{pH}$ in the optimal range, $\mathrm{Al}$-monomer or other Al-oligomer species tend to be further hydrolyzed and transform to $\mathrm{Al}_{13}$ and the content of $\mathrm{Al}_{13}$ increases rapidly with the increasing of $B$ value. It agrees with the reports of previous researchers (Hsu, 1988; Akitt and Alan, 1981; Bottero et al., 1987, 1988; Brosset, 1952; Rowsell and Nazar, 2000; Allouche et al., 2000). In case of the $\mathrm{pH}$ over the maximum of the optimal range, the content of $\mathrm{Al}_{13}$ decreases due to the condensation or aggregation of $\mathrm{Al}_{13}$. In case of the $\mathrm{pH}$ below the minimum of the optimal range it is difficult to produce $\mathrm{Al}_{13}$ in $\mathrm{PACl}$. No $\mathrm{Al}_{13}$ can form at $\mathrm{pH}$ of 2.73. In our recent study on the purification of $\mathrm{Al}_{13}$ (Wang et al., 2005), the $\mathrm{pH}$ of the $\mathrm{Al}_{13}$ solutions obtained are 5.15, 4.96 and 4.81 corresponding the concentrations of $0.42,1.06$ and $2.11 \mathrm{~mol} / \mathrm{L}$ respectively. It is close to the optimal range of $\mathrm{pH}$ for the formation of $\mathrm{Al}_{13}$ and much higher than in the $\mathrm{PACl}$ prepared by adding base in $\mathrm{AlCl}_{3}$ solution at the same concentration. It demonstrates that high concentration $\mathrm{Al}_{13}$ can exist under the condition of proper $\mathrm{pH}$.

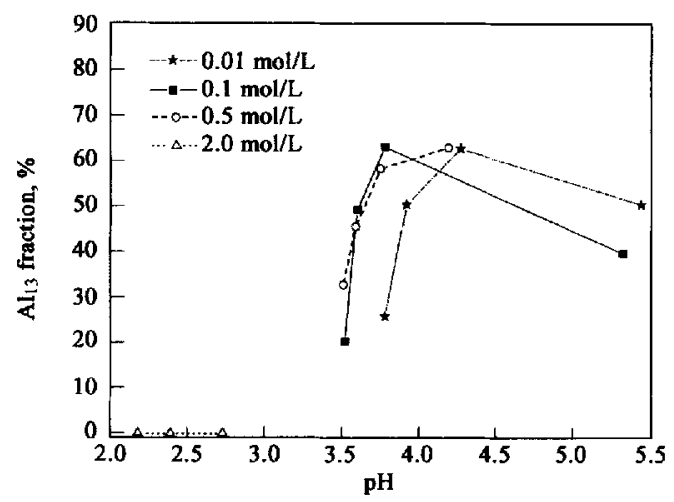

Fig.7 Content of $\mathrm{Al}_{13}$ fraction in $\mathrm{PACl}$ prepared in various $\mathrm{Al}(\mathrm{III})$ concentrations and the corresponding $\mathrm{pH}$ values

$B$ value is $1.0,1.5,2.0,2.5$ with the increasing of $\mathrm{pH}$ respectively in each line except the line of $\mathrm{Al}$ (III) concentration of $0.5 \mathrm{~mol} / \mathrm{L}$; the $B$ value of $\mathrm{Al}$ (III) concentration of $0.5 \mathrm{~mol} / \mathrm{L}$ is $2.0,2.2,2.4$, 2.5 with the increasing of $\mathrm{pH}$ respectively

By referring back Fig.6, the $\mathrm{Al}_{13}$ disappears until the concentration concentrated to $2.0 \mathrm{~mol} / \mathrm{L}$ where the $\mathrm{pH}$ value is about 2.9 (Table 3). It indicates that $\mathrm{Al}_{13}$ can not exist for long period and will be decomposed very soon by $\mathrm{H}^{+}$at $\mathrm{pH}$ below the minimum of optimal range and transform to other species. For $\mathrm{PACl}$ in low concentration, the $\mathrm{pH}$ value is higher and $\mathrm{Al}_{13}$ is 
formed; for $\mathrm{PACl}$ in high concentration, the $\mathrm{pH}$ is lower and no $\mathrm{Al}_{13}$ is formed. Although the tetrahedral $\mathrm{Al}(\mathrm{OH})_{4}^{-}$can form at the interface of the base and the bulk solution by adding base into $\mathrm{AlCl}_{3}$ solution, it reacts with $\mathrm{H}^{+}$at once and is decomposed rapidly at the low $\mathrm{pH}$. And $\mathrm{H}^{+}$will promote the decomposition of $\mathrm{Al}_{13}$ when formed in the interface during base addition (Furrer et al., 1999). The products of decomposition of $\mathrm{Al}_{13}$, such as Al-oligomer can react with $\mathrm{OH}^{-}$to form $\mathrm{Al}_{\mathrm{c}}$. Therefore, even if a little $\mathrm{Al}_{13}$ has formed at $B=2.5$ in high concentration $\mathrm{PACl}$, it can not exist for a long period and will be decomposed very soon in low $\mathrm{pH}$. As a result, the content of $\mathrm{Al}_{13}$ decreases and $\mathrm{Al}_{c}$ increases rapidly with the increasing of $\mathrm{Al}(\mathrm{III})$ concentration.

The formation of $\mathrm{Al}_{13}$ in diluted solution of 2.0 $\mathrm{mol} / \mathrm{L} \mathrm{PACl}$ is similar with base addition into $\mathrm{Al}(\mathrm{III})$ solution. Fig. 8 shows the variation of $\mathrm{pH}$ of $2.0 \mathrm{~mol} / \mathrm{L}$ $\mathrm{PACl}$ diluted to various concentrations with aging time. The $\mathrm{pH}$ of $\mathrm{PACl}$ is increasing rapidly during dilution. The $\mathrm{pH}$ is higher in lower concentration. Based on the deduction of optimal $\mathrm{pH}$ range for $\mathrm{Al}_{13}$, $\mathrm{i}$. e. from 3.5 to 5 , the $\mathrm{pH}$ of $\mathrm{PACl}$ in concentration below $0.5 \mathrm{~mol} / \mathrm{L}$ favors the formation of $\mathrm{Al}_{13}$. Fig. 9 shows that the $\mathrm{pH}$ value measured in diluted $\mathrm{PACl}$ is higher than that by calculation. Since larger polymers are the predominance species in high concentration $\mathrm{PACl}$, the increase of $\mathrm{pH}$ is probably attributed to the decreasing of $\mathrm{H}^{+}$concentration by dilution and the consumption of $\mathrm{H}^{+}$by decomposition of larger polymer mainly. This $\mathrm{H}^{+}$consumption causes the micro-interfacial $\mathrm{pH}$ gradient and makes the formation of tetrahedral Al-O possible. Once the tetrahedral Al has formed, it can react with oligomer to form $\mathrm{Al}_{13}$. Since the rate of decomposition of larger polymer is very slow at the optimal $\mathrm{pH}$ range, the formation of $\mathrm{Al}_{13}$ is a continuous process.

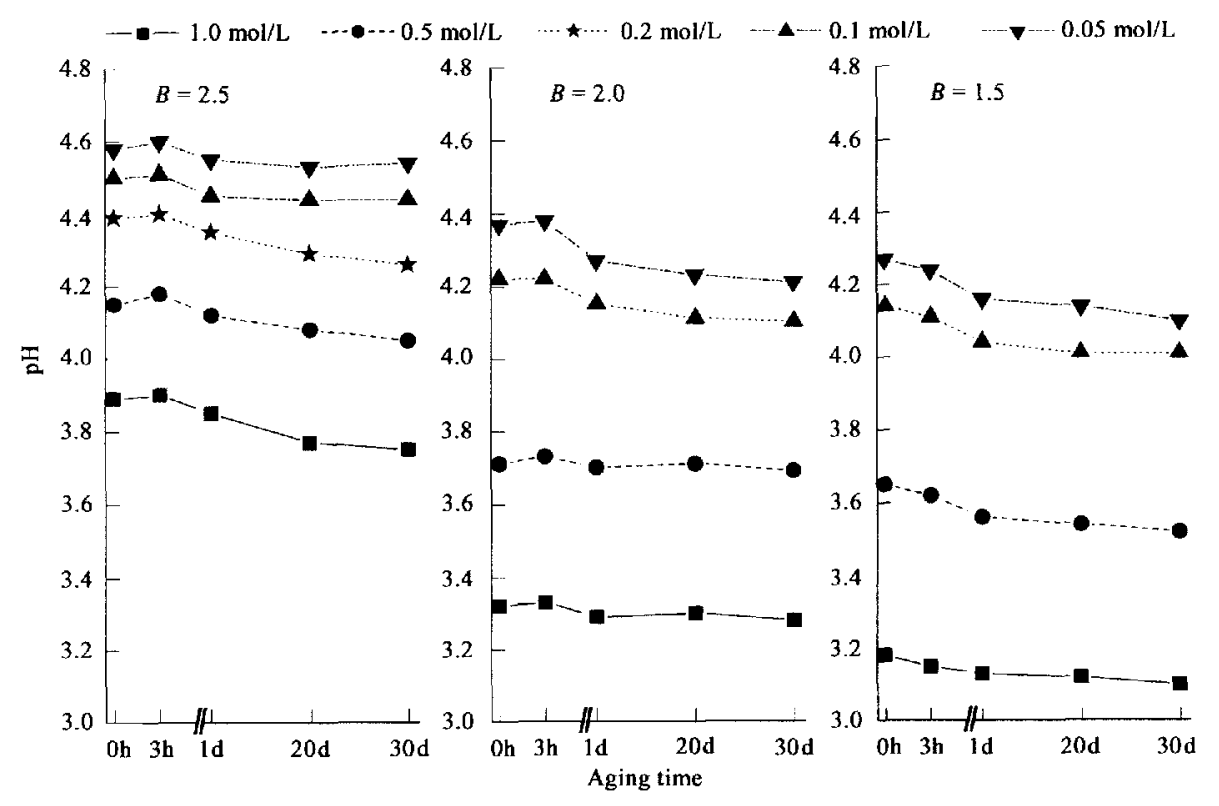

Fig. 8 Variation of $\mathrm{pH}$ value with aging time of $\mathrm{PACl}$ in various $B$ during dilution

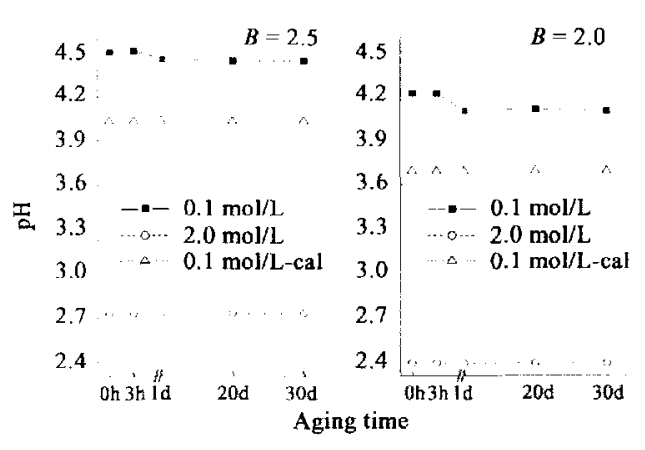

Fig. 9 Comparison of $\mathrm{pH}$ increment in diluted $\mathrm{PACl}$

The results suggest the possibility that the preparation of $\mathrm{PACl}$ at concentration exceeding 2.0 mol/L with high $\mathrm{Al}_{13}$ fraction may be achieved only if the $\mathrm{pH}$ of the system can be maintained at high level, e.g. 4.0 under the condition of $B$ value below 2.5. The processing of electrolysis or concentration by ultrafiltration could be one of the promising techniques to be applied in the high $\mathrm{Al}_{13}-\mathrm{PACl}$ production because the $\mathrm{pH}$ value of the system can be controlled.

\section{Conclusions}

The effect of total $\mathrm{Al}(\mathrm{III})$ concentration on the hydrolyzed products over the range of concentration from 0.5 to $2.0 \mathrm{~mol} / \mathrm{L}$ in partial neutralized $\mathrm{Al}$ (III) solution is significant. The $\mathrm{pH}$ value of solution plays a very important role. This study demonstrates that the formation and stabilization of $\mathrm{Al}_{13}$ are radically influenced by $\mathrm{pH}$ which is the function of $\mathrm{Al}$ (III) concentration and $B$ value. The main reason of 
disappearance of $\mathrm{Al}_{13}$ in high concentration $\mathrm{PACl}(>$ $2.0 \mathrm{~mol} / \mathrm{L}$ ) is the very low $\mathrm{pH}$ value. The results indicates that the hydrolysis mechanism of $\mathrm{Al}$ (III) in high $\mathrm{Al}(\mathrm{III})$ concentration is different from that in low $\mathrm{Al}$ (III) concentration by base adding into $\mathrm{AlCl}_{3}$ solution.

\section{References:}

Akitt J W, Farthing A, 1978. New ${ }^{27}$ Al NMR studies of the hydrolysis of the aluminum (III) cation [J]. J Magnetic Resonance, 32: 345 352.

Akitt J W, Alan F, 1981. Alumimum-27 nuclear magnetic resonance studies of the hydrolysis of aluminum (III): Part 4. Hydrolysis using sodium carbonate[J]. J Chem Soc Dalton Trans, 7: 16171623.

Akitt J W, 1989. Multinuclear studies of sluminum compounds [J] Progress in NMR Spectroscopy, 21: 1-149.

Allouche L, Gerardin C, Loiseau T et al., 2000. A130: A giant aluminum polycation[J]. Angew Chem, 112(3): 521-524.

Bersillon J L, Hsu P H, Fiessinger F, 1980. Characterization of hydroxy-aluminum solution[J]. Soil Sci Soc Am, 44: 629-634.

Bottero J Y, Axelos M, Tchoubar D et al, 1987. Mechanism of formation of aluminum trihydroxide from keggin $\mathrm{Al}_{13}$ polymers [J]. J Colloid and Interface Science, 117(1): 47-57.

Bottero J Y, Tchoubar D, Cases J M et al., 1988. New developments in knowledge of aluminum colloids, interfacial phenomena in biotechnology and material processing[M]. Amsterdam: Elsevier Science Publishers B. V. 459-479.

Brosset $\mathrm{C}, 1952$. On the reactions of the aluminum ion with water [J]. Acta Chem Scand, 6: 910-940.

Furrer G, Gfeller M, Wehrli B, 1999. On the chemistry of the keggin $\mathrm{Al}_{13}$ polymer: Kinetics of proton-promoted decomposition [J]. Geochimica et Cosmohimica Acta, 63(19/20): 3069-3076.

Hsu P H, 1988. Mechanism of gibbsite crystallization from partially neutralized aluminum chloride solutions clays and clay minerals [J]. Clays and Clay Minerals, 36(1): 25-30.
Kloprogge J T, Seyken D, Geus J W et al., 1993. The effects of concentration and hydrolysis on the oligomerization and polymerization of $\mathrm{Al}(\mathrm{III})$ as evident from the ${ }^{27} \mathrm{Al}$ NMR chemical shifts and linewidths[J]. Non-Crystalline Solids, 160: 144-151.

Parker D R, Bertsch P M, 1992. Identification and quantification of the " $\mathrm{Al}_{13}$ " tridecameric polycation using ferron[J]. Environ Sci Tech, 26: $908-914$.

Parthasarathy N, Buffle J, 1985. Study of polymeric aluminum (III) hydroxide solution for application in waste water treatment. Properties of the polymer and optimal conditions of preparation [J]. Water Research, 19:25-36.

Rowsell J, Nazar L F, 2000. Speciation and thermal transformation in alumina sols: structures of the polyhydroxyoxoaluminum cluster $\left[\mathrm{Al}_{30} \mathrm{O}_{8}(\mathrm{OH})_{5 \mathrm{~s}}\left(\mathrm{H}_{2} \mathrm{O}\right)_{2 n}\right]^{18 t}$ and its $\delta$-keggin moieté [J], $\mathrm{J}$ Am Chem Soc, 122: $3777-3778$.

Stumm W, Morgan J J, 1962. Chemical aspects of coagulation[J]. J Am Wat Wks Ass, 54: $971-994$.

Tang H X, Luan Z K, 1996. The different behavior and mechanism between inorganic polymer flocculant and traditional coagulants [M]. In: Chemical water and wastewater treatment (IV) (Hahn $\mathrm{H}$. H. el $a d$., ed.). New York: Springer-Verlag. 83-93.

Tang H X, 1998. The flocculation morphology of hydroxyl polyaluminum chloride[J]. Acta Circum Sinica, 18(1): 1-10.

Wang $\mathrm{D} \mathrm{S}$, Tang $\mathrm{H} \mathrm{X}, 2001$. Modified inorganic polymer flocculants-PFSi: Its preparation, characterization and coagulation behavior[J]. Water Res, 35(14): 3418-3428.

Wang D S, Tang H X, Gregory J, 2002. Relative importance of charge-neutralization and precipitation during coagulation with IPF-PACl: Effect of sulfate[J]. Environ Sci Tech, 36(8): 18151820 .

Wang D S, Sun W, Xu Y et al., 2004. Speciation stability of inorganic polymer flocculant-PACI[J]. Colloids and Surfaces, 243: 1-10.

Wang D S, Liu H, Lv C H et al., 2006. Removal of humic acid by coagulation with nano-A $]_{13}[$ J]. Water Supply, 6(1): 59-67.

$\mathrm{Xu} \mathrm{Y,} \mathrm{Wang} \mathrm{D} \mathrm{S,} \mathrm{Liu} \mathrm{H} \mathrm{et} \mathrm{al.,} \mathrm{2003.} \mathrm{Optimization} \mathrm{on} \mathrm{the} \mathrm{separation} \mathrm{and}$ purification of $\mathrm{Al}_{13}[\mathrm{~J}]$. Colloids and Surfaces, 231: $1-9$.

(Received for review November 2, 2005. Accepted December 6, 2005) 